\title{
Alleviation of atopic dermatitis-related indications of the Lonicera japonica aqueous fraction produced by solid-state fermentation
}

\author{
Chi-yeol Yoo ${ }^{1}$, Hyeong-U Son ${ }^{1}$, Jong-Myung Kim ${ }^{2}$, Sang-Han Lee ${ }^{1,3 *}$ \\ ${ }^{1}$ Department of Food Science \& Biotechnology, Graduate School, Kyungpook National University, Daegu 41566, Korea \\ ${ }^{2}$ Research Institute of Biotechnology, Farmbios Co., Ltd., Daegu 41566, Korea \\ ${ }^{3}$ Food \& Bio-Industry Research Institute, and Department of Food Science \& Biotechnology, \\ Kyungpook National University, Daegu 41566, Korea
}

\section{고체발효를 통한 인동 추출물의 항아토피 활성 증진효과 분석}

\author{
유치렬 ${ }^{1} \cdot$ 손형우 $^{1} \cdot$ 김종명 $^{2} \cdot$ 이상한 ${ }^{1,3 *}$ \\ ${ }^{1}$ 경북대학교 식품공학부, ${ }^{2}$ 주식회사 팜바이오스, ${ }^{3}$ 경북대학교 식품생물산업연구소
}

\begin{abstract}
In the process of screening the extracts of various medicinal herbs exhibiting with potent anti-atopic activity, we first confirmed the effect of the anti-atopic activity of the aqueous fraction of Lonicera japonica stem extract (afLj) ontained by the solid fermentation process by Phellinus baumii was identified to show anti-atopic activity for the first time. Further animal experiments revealed that the antioxidative activity of afL $j$ had decreased, while the anti-atopic activity was increased compared to control. Moreover, treatment with afLj significantly decreased the infiltration of immune cells into inflammatory sites to $32 \%$ level observed with the control treatment in a DNFB-induced mouse model (NT). In particular, afLj dramatically decreased the number of eosinophils by afL $j$ than those compared to $\mathrm{Lj}$. The overall decrease in antioxidant activity and lack of significant differences in the $\beta$-hexosaminidase activity of afL $j$ imply that the activity possessed by $L j$ itself was converted into an anti-atopic active substance through biotransformation during solid fermentation. Overall, these results suggest that the potential of afL $j$ will be possible to use as a new functional biomaterial or functional food ingredient related with anti-atopic benefits.
\end{abstract}

Key words : Lonicera japonica, Phellinus baumii, solid fermentation, atopic dermatitis, DNFB (dinitrochlorobenzene)

\section{서 론}

아토피 피부염(atopic dermatitis)은 급작스럽게 발병하여 염증을 동반한 가려움을 유발하는 만성 피부질환이다. 아 토피 피부염은 환자에게 극도로 심각한 통증과 스트레스를 주는 질환으로, 이의 예방과 치료에는 여러 가지 시도가 있었다. 아토피 피부염을 일으키는 주요 원인으로는 면역 학적 요인, 환경적 요인, 유전적 요인으로 크게 세 가지로

*Corresponding author. E-mail : sang@knu.ac.kr Phone : 82-53-950-7754, Fax : 82-53-950-6577

Received 28 May 2019; Revised 15 July 2019; Accepted 15 July 2019.

Copyright (c) The Korean Society of Food Preservation. All rights reserved.
분류할 수 있는데, 환경적 또는 면역학적 요인보다는 유전 적인 영향이 중요하게 작용한다고 볼 수 있다. 현재 약 70 개 의 유전자가 아토피 피부염과 관련이 있다고 보고되었으 며, 관련 유전자의 다형성(polymorphism)은 인종에 따라서 분포가 다르다(1).

한편, 다른 피부질환과는 달리 아토피 피부염의 피부병 변에 침윤하는 염증세포는 주로 Th2 세포로서 IL-4, IL-5, $\mathrm{IL}-13$ 등의 사이토카인을 과다하게 생성하여 혈중 $\mathrm{IgE}$ 의 상승을 촉진하고, eosinophil의 증가를 유도하며, 비정상적 인 monocyte에 의해 prostaglandin $\mathrm{E}$ 의 생성이 증가하게 되 고, 이로 인하여 $\mathrm{Th} 1$ 림프구의 침윤이 억제된다. 또한 $\mathrm{Th} 1$ 림프구는 아토피 피부염에서 쉽게 활성화되는 spleen cell로 부터 유리된 TNF- $\alpha$ (tumor necrosis factor- $\alpha$ )에 의해서도 억 제된다. 결국, 아토피 피부염에서 $\mathrm{Th} 1$ 증식을 억제하고, 
세포매개성 면역의 저하를 초래하게 된다. 각종 사이토카 인(cytokines)은 혈관 내피세포를 활성화하여 여러 세포유 착분자(cell adhesion molecules)의 발현을 유도하거나 증가 시켜 T림프구(memory 계열의)의 복귀를 촉진시킴으로서 습진성 병변을 유발한다(2). 현재 사용되는 치료제로는 부 신피질 호르몬제, 항히스타민제, 감마-인터페론 등이 사용 되어 유의성 있는 치료효과를 보이고 있으나, 일부 환자들 에게는 치료 반응이 적거나, 과민 반응 및 신독성, 간독성 등으로 인한 부작용이 문제가 되고 있다(3). 천연물을 원료 로 한 신약 및 기존의 치료제에 천연물을 배합한 형태의 보습제, 국소 도포제 등의 개발도 활성화되기를 기대하면 서, 다양한 천연물의 항염증, 항산화, 항균 및 소양감 억제 작용 등의 많은 연구 결과가 보고되고 있으므로 좋은 치료 방법이 도출되기를 기대할 수 있다(4).

인동은 일본, 중국 및 우리나라의 전국 각 처의 산야지 해발 50-600m 지역 산기슭 및 인가 부근의 둑에 자생하는 반 상록 덩굴성 관목으로서, 꽃 봉우리는 금은화, 줄기와 가지는 인동등(忍冬藤)이라 한다. 인동은 수 세기동안 이뇨, 해독, 종기, 부종, 감기, 지형, 정혈, 구토 및 염증 등에 사용 되어 왔는데, 현재 알려진 바에 의하면, 인동의 함유 성분으 로는, caffeoylquinic acid, chlorogenic acid, iso-chlorogenic acid 등의 가수분해형 tannin류와, loganin, sweroside, vogeloside, epi-vogeloside 등의 배당체의 iridoidglycoside 류, ronicerin, rhoifolin, orchnaflavon 등의 플라보노이드류, hedoragenin, oleanolic acid를 비당부로 갖는 triterpene계 saponin류 등이 알려져 있다(5).

이와 같이 인동은 인동과(Caprifoliaceae)에 속하는 인동 꽃과 덩굴로서, 동양의학에서는 호흡기 감염, 당뇨병 및 관절염 치료와 독소에 대한 중화작용 및 해열제로 활용되어 왔다. 국내 금은화에 관련된 논문은 금은화 추출물의 세포 보호 효과, 미생물 발효 생성물의 항산화 효과, 항균·항염 등이 있다(6). 통상적으로 진균류에 의하여 고체발효를 거 치면 기질인 식물은 보유한 활성이 저하하는 것이 일반적이 다. 그럼에도 불구하고 본 연구에서는 약 200 여종의 한약재 또는 식품의 소재로 사용가능한 식물에 대하여 독성성분을 저감시킬 의도로 고체발효를 하였으며 그 고체발효의 추출 물에서 항아토피 활성이 증진된 인동 추출물을 발견하였으 므로 이에 보고하고자 한다.

\section{재료 및 방법}

\section{시료의 준비 및 고체발효}

실험에 사용한 인동(Lonicera japonica)은 대구 약령시장 인 약전골목에서 2017년 4월 구입하여 이의 줄기(stem) 부 분을 사용하였으며, 이는 voucher specimen (2017-Lj)으로 경북대 식품효소생물공학연구실(농생대3-213호)에 보관 중에 있다. 사용 전에 세척하여 불순물을 제거한 후 탈수하
였으며 이를 $121^{\circ} \mathrm{C}, 20$ 분간 멸균하여 준비하였다(Fig. 1a). 인동 $100 \mathrm{~g}$ 을 $1 \mathrm{~L}$ 플라스크에 넣고, 10 배 부피의 $\mathrm{DW}$ 를 첨가하여 2시간 동안 진탕시킨 후 72 시간 침지하고 10,000 $\mathrm{rpm}$ 으로 10 분간 원심분리 후 상등액을 취하였으며, 이를 동결 건조하여 각 용매에 녹여 실험에 사용하였다.

고체발효에 사용된 상황버섯(Phellinus baumii)균사체는 (주)팜바이오스에서 관리하는 균사체를 이용하였다. 상황 버섯 균사체를 potato dextrose agar(Difco Laboratories, Detroit, MI, USA) 평판배지에서 $25^{\circ} \mathrm{C}$ 로 일주일간 배양하 고, 이에 배지 $1 \times 1 \mathrm{~cm}$ 를 잘라내어 potato dextrose broth (Difco) 조건의 flask에 접종하여 shaking incubator(JSSI-300C, JSResearch, Kongju, Korea)에서 $25^{\circ} \mathrm{C}$ 의 조건으로 3 주간 배양하였다. 준비된 상황버섯 배양액을 멸균된 인동에 접 종하고, incubator에서 $25^{\circ} \mathrm{C}$ 조건으로 고체발효를 하였다. 고체발효의 결과, 백색의 상황 버섯균 포자를 확인하였고 (Fig. 1b), 이를 인동 원물 추출과 동일한 방법으로 추출 및 동결 건조하여 실험에 이용하였다.
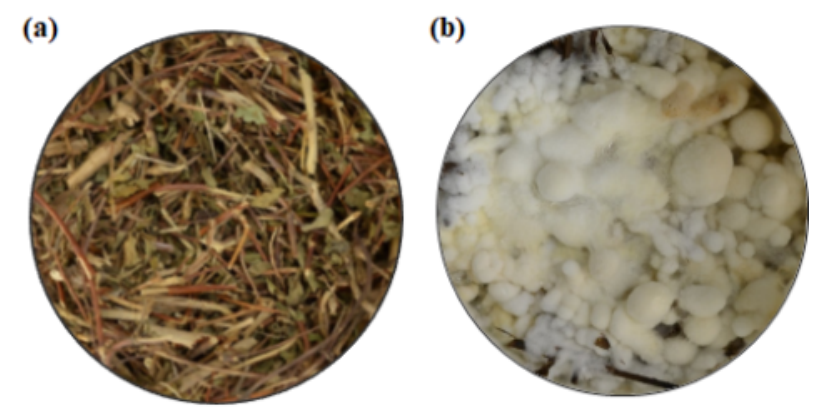

Fig. 1. A Classical appearance of Lonicera japonica stem and solid fermentation process.

(a) Dried $L$ japonia was cut and autoclaved for sterilization (b) The autoclaved sample was cocultured with mycelia of Phellinus baumii for 2 weeks. The white color denotes spores and underlying $L$ japonica changed color as well as textures of the sample.

\section{실험동물 준비 및 관리}

실험에 사용된 동물은 (주)샘타코코리아(Osan, Korea)에 서 공급받은 4-5주령의 수컷 C57BL6마우스를 사용하였다. 공급받은 마우스는 마우스용 케이지 $(220 \times 200 \times 145 \mathrm{~mm})$ 에 서 1 주일간 순화시킨 후 실험에 사용하였다. 동물 실험실의 사육 환경은 온도 $22 \pm 2^{\circ} \mathrm{C}$, 상대습도 $55 \pm 5 \%$, 조명주기 12 시 간, 조도 200 lux로 조절하면서 사육하였다. 급이 사료는 pellet형 고형사료인 purina rat chow를 Nestle Purina Pet Care Korea Ltd. (Seoul, Korea)로부터 공급받아 자유롭게 섭취할 수 있도록 하였으며, 음수도 멸균 정제수를 자유롭 게 섭취하도록 하였다. 위의 모든 동물실험의 지침은 동물 실험 윤리위원회의 제반 규정을 엄격하게 준수하면서 실험 하였다(KNU-2017-0072).

\section{DNFB 처리에 의한 아토피 유발 마우스 모델}

접촉성 유도에 의한 알러지 완화 활성은 다음과 같이 
수행하였다. 순화 과정을 거친 마우스에 $0.5 \% \mathrm{DNFB}$ (dinitrochlorobenzene benzene; Sigma, St. Louis, WA, USA) 를 acetone: olive oil 의 용매에 4:1의 비율로 희석하여 용액 $50 \mu \mathrm{L}$ 를 해당 마우스의 복부에 주사하였으며, $6,7,8,10$, 14,16 일에 $0.2 \%$ DNFB (acetone: olive oil $=4: 1$ ) 용액 20 $\mu \mathrm{l}$ 를 총 6 회에 걸쳐 귀 부위에 도포하여 재감작 (resensitization)시켜 아토피를 유발시켰다. 한편, 시료의 경 우는 DNFB 처리 후 아토피 유발 마우스의 귀 표면에 9, $11,12,13,15,17$ 일에 시료 $20 \mu \mathrm{L}(100 \mu \mathrm{g} / \mathrm{mL})$ 를 총 6회에 걸쳐 도포하였다. 시험 마지막인 19 일에 귀를 절개 후, $10 \%$ 포름알데히드에 고정하였다. 샘플은 $\mathrm{Lj}$ (인동의 잎의 물 추 출물) 또는 $\mathrm{afLj}$ (인동의 잎에 상황버섯 균사체로 고체발효 시킨 물 추출물)로 지칭하였다. 고정된 검체는 수세 및 탈수, 파리핀 포매 과정을 거쳐 5-6 $\mu \mathrm{m}$ 의 크기로 절편을 제작한 후, hematoxylin-eosin (HE)을 이용하여 염색하여 현미경으 로 관찰하였으며(7), ear thickness, ear epidermis thickness, total cell counting 및 eosinophil counting은 전보(8)에 준하여 측정하였다.

\section{Cell viability}

Rat 비만세포인 RBL-2H3은 10\% fetal bovine serum (FBS, Hyclone, Logan, UT, USA), 1\% penicillin-streptomycin(Hyclone, USA)이 첨가된 Dulbecco's modified eagle medium(DMEM, Hyclone, USA) 배지를사용하여 $37^{\circ} \mathrm{C}, 5 \% \mathrm{CO}_{2}$ incubator(MCO-18AIC, Sanyo, Gunma, Japan) 조건에서 배양하였다. 세포의 생존율 은 MTT (3-[4,5- dimethylthiazole-2-yl]-2,5-diphenyl-tetrazolium bromide(Sigma, St. Louis, WA, USA)를 이용하여 측정하였다. $\mathrm{RBL}-2 \mathrm{H} 3$ 세포를 $1 \times 10^{5}$ cells $/ \mathrm{mL}$ 의 농도로 준비하여 96-well plate에 $200 \mu \mathrm{L}$ 씩 분주한 뒤 시료를 첨가하고 18 시 간 배양한 후, 배지를 제거하고 FBS가 포함되지 않은 DMEM 배지 $100 \mu \mathrm{L}$ 과 $10 \mu \mathrm{L}$ MTT 용액 $(5 \mathrm{mg} / \mathrm{mL})$ 을 가하고 1 시간 더 배양하였다. 환원된 formazan을 측정하기 위하여, 배지를 제거하고 DMSO $200 \mu \mathrm{L}$ 를 넣어 녹인 후, ELISA reader(Perkin Elmer, Waltham, MA, USA)를 이용하여 570 $\mathrm{nm}$ 에서 흡광도를 측정하였다. 세포 생존율은 시료를 첨가 하지 않은 값을 $100 \%$ 로 계산하여 상대적으로 비교하였다.

\section{$\beta$-Hexosaminidase assay}

$\beta$-Hexosaminidase assay는 Chung 등(9)의 방법을 변형하 여 실험하였다. RBL-2H3세포를 $0.5 \mu \mathrm{g} / \mathrm{mL}$ 의 DNP-IgE (dinitrophenyl immunoglobulin E, Sigma)가 첨가된 배지에 $1 \times 10^{5}$ cells $/ \mathrm{mL}$ 의 농도로 96-well plate에 $200 \mu \mathrm{L}$ 씩 분주한 뒤, $\mathrm{CO}_{2}$ incubator(MCO-18AIC, Sanyo, Gunma, Japan)에서 $12 \mathrm{~h}$ 동안 배양하였다. 그 다음, 상층액을 제거하고, siraganian buffer $(119 \mathrm{mM} \mathrm{NaCl}, 5 \mathrm{mM} \mathrm{KCl}, 5.6 \mathrm{mM}$ glucose, $0.4 \mathrm{mM} \mathrm{MgCl} 2,25 \mathrm{mM}$ PIPES, $1 \mathrm{mM} \mathrm{CaCl}, 0.1 \%$ BSA, $\mathrm{pH}$ 7.2)로 2회 세척한 다음 $\mathrm{FBS}$ 가 제외된 $\mathrm{DMEM}$ 배지에
시료를 $20 \mathrm{jg} / \mathrm{mL}$ 로 처리하여 $37^{\circ} \mathrm{C}, 5 \% \mathrm{CO}_{2}$ incubator(MCO-18AIC, Sanyo, Gunma, Japan)에서 $30 \mathrm{~min}$ 동안 더 배양시켰다. 2 $\mu \mathrm{g} / \mathrm{mL}$ DNP- BSA (albumin from bovine serum, 2,4-dinitrophenylated, Sigma, St. Louis, WA, USA)을 가하여 $37^{\circ} \mathrm{C}, 5 \% \mathrm{CO}_{2}$ incubator(MCO-18AIC, Sanyo, Gunma, Japan) 에서 2시간 동안 배양시킨 후, 상층액 $40 \mu \mathrm{L}$ 를 96-well plate 에 옮기고 substrate buffer (4-p-nitrophenyl-N-acetyl- $\beta$ -D-glucosaminide $2 \mathrm{mM}$, sodium citrate, $0.05 \mathrm{M}, \mathrm{pH} 4.5$ )를 $40 \mu \mathrm{L}$ 넣고 1 시간 동안 다시 배양시켰다. $200 \mu \mathrm{L}$ 의 반응정지 액을 첨가하여 반응을 종결시킨 후 spectrophotometer(Perkin Elmer, Waltham, MA, USA)를 이용하여 $405 \mathrm{~nm}$ 에서 흡광도 를 측정하였다.

\section{$\mathrm{DPPH}$ radical 소거 활성}

Free radical-scavenging activity는 radical인 1,1-diphenyl2-picryhydrazyl(DPPH)을 이용하여 Kang 등(10)의 방법을 변형하여 실험하였다. 각 용매 추출물의 농도 별 시료 10 $\mu \mathrm{L}$ 와 $0.2 \mathrm{mM}$ DPPH(1,1-Diphenyl-2-picrylhydrazyl) $190 \mu \mathrm{L}$ 를 혼합하여 상온에서 10 분간 반응시킨 후 $517 \mathrm{~nm}$ 에서 흡광도를 측정하여 DPPH radical 소거활성 비율 (\% inhibition)을 아래와 같은 방법으로 계산하였다.

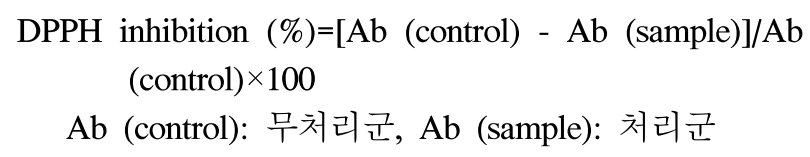

\section{Ferric Reducing Antioxidant Power (FRAP)}

활성측정 시료에 대한 ferric reducing antioxidant power assay (FRAP)는 일반적으로 널리 이용되는 색의 변화로서 항산화능을 측정하는 $\mathrm{Heo}$ 등(11)의 방법을 변형하여 사용 하였다. $\mathrm{C}_{2} \mathrm{H}_{3} \mathrm{NaO}_{2}$ 와 acetic $\operatorname{acid}\left(\mathrm{C}_{2} \mathrm{H}_{4} \mathrm{O}_{2}\right)$ 를 이용하여 acetate buffer(pH 3.6, $23 \mathrm{mM}$ )를 조제하고 $40 \mathrm{mM} \mathrm{HCl}$ 과 TPTZ(2,4,6-tripyridyl-s-triazine)를 이용하여 $10 \mathrm{mM}$ TPTZ solution을 만들었다. 반응용액은 acetate buffer $(\mathrm{pH} \mathrm{3.6,23}$ $\mathrm{mM}), 10 \mathrm{mM}$ TPTZ (2,4,6-tripyridyl-s-triazine) 및 $20 \mathrm{mM}$ $\mathrm{FeCl}_{3} \cdot 6 \mathrm{H}_{2} \mathrm{O}$ 를 $10: 1: 1$ 의 비율로 섞어 만든 후, 실험 전까지 $37^{\circ} \mathrm{C}$ 를 유지하였으며, 96-well plate 마이크로 플레이트 (well volume: $200 \mu \mathrm{L})$ 에 용매별 시료 $(2 \mu \mathrm{L})$ 와 발색시약(198 $\mu \mathrm{L}$ )을 처리한 다음, 약 30 분 간 암소에서 방치한 후 590 $\mathrm{nm}$ 에서 흡광도를 측정하였다.

\section{CUPRAC assay}

Cupric ion reducing antioxidant capacity assay는 Apak의 방법(12)을 변형하여 측정하였다. $\mathrm{DW}, 10 \mathrm{mM} \mathrm{CuCl}_{2}, 75$ $\mathrm{mM}$ neocuproine을 제조하고, 각각을 실험 직전에 100:1:1 비율로 혼합하여 사용하였다. 시료를 96-well plate에 각각 $2 \mu \mathrm{L}$ 주입하고 혼합된 CUPRAC solution $198 \mu \mathrm{L}$ 를 첨가한 
후 $37^{\circ} \mathrm{C}$ 에서 빛을 차단한 상태로 20 분간 반응시킨 후 450 $\mathrm{nm}$ 에서 흡광도를 측정하였다.

\section{통계학적 분석}

실험결과는 ANOVA Tukey post-hoc test로 통계적 유의 성을 엑 셀프로그램으로 $\mathrm{SD}$ (standard deviation) 값을 구하여 산정하였다. 유의차가 $\mathrm{p}<0.05$ 일 때 통계적 유의성을 인정하 였다.

\section{결 과}

아토피 유발 마우스 모델에서의 인동발효추출물 $(a f L j)$ 의 활성 변화

인동의 발효 유무에 따라 제조된 추출물의 항아토피 활 성을 확인하였다. $\mathrm{DNFB}$ 를 마우스 귀에 처리한 결과, 소양 감, 홍반, 부스럼 등이 육안 상 확인되었다. 시료 처리군 별 외형적인 증상을 확인한 결과, 인동 추출물 $(\mathrm{Lj})$ 에서는
$\mathrm{DNFB}$ 를 처리한 마우스와 거의 유사한 형태를 보였으나, 인동발효추출물 $(\mathrm{afLj})$ 을 처리한 마우스에서는 무처리구 (NT)와 유사할 정도로 아토피 증상이 완화되는 것을 확인 하였다(Fig. 2a). 특히, 이러한 증상이 복합적으로 일어날 경우 귀의 두께가 Fig. $2 \mathrm{~b}$ and c에서 보듯이 비정상적으로 두꺼워지는데, 이들 귀의 두께를 $\mathrm{DNFB}$ 를 $100 \%$ 로 하였을 때, 상대적으로 귀의 두께의 감소를 계산해 본 결과, $\mathrm{Lj}$, afLj에서 각각 $96 \%, 73 \%$ 로, 귀의 표피층 두께(ear epidermis thickness)는 $\mathrm{Lj}$, afLj에서 각각 $110 \%, 71 \%$ 로 나타났다(Fig. $2 \mathrm{~d}$ and e). 또한, 염증부위의 면역세포 침투현상을 확인하기 위하여, 동일한 면적 내의 총 세포수는 DNFB 마우스 대비 $\mathrm{Lj}, \mathrm{afLj}$ 에서 각각 $67 \%, 32 \%$ 값을 나타냈으며, 호산구는 각각 $50 \%, 22 \%$ 값으로 감소한 것으로 알 수 있었다(Fig. $2 \mathrm{f}$ and $\mathrm{g})$. 따라서, 본 실험 결과에서는 인동 $(\mathrm{Lj})$ 추출물

항아토피 활성은 미미했던 반면, 인동 발효(afLj) 추출물에 서는 항아토피 활성이 인동 추출물에 비교하여 훨씬 증가한 것으로 확인되었다.

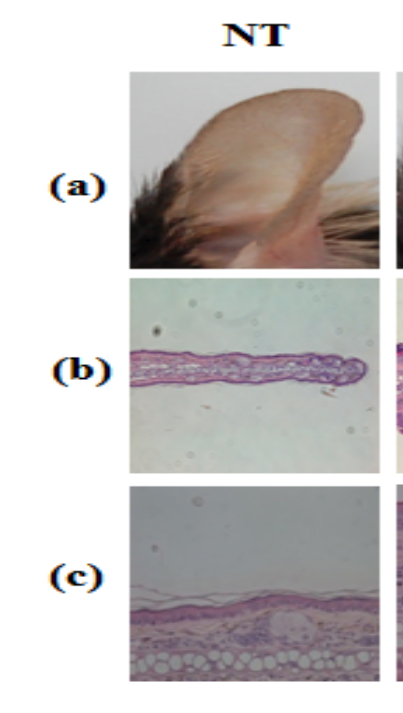

DNFB
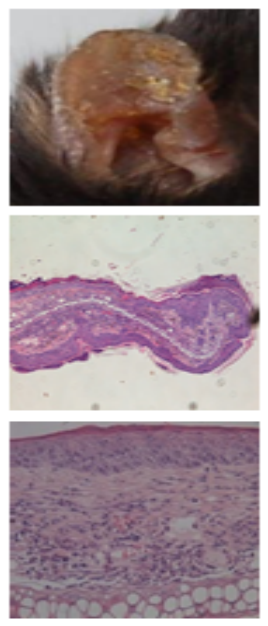

Li

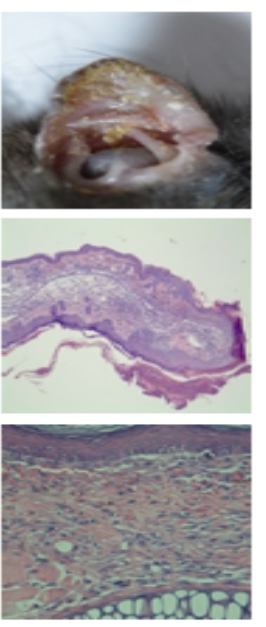

afti

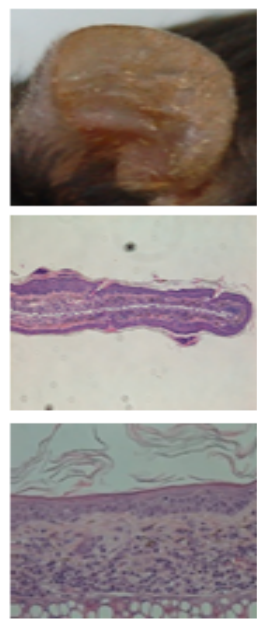

(d)

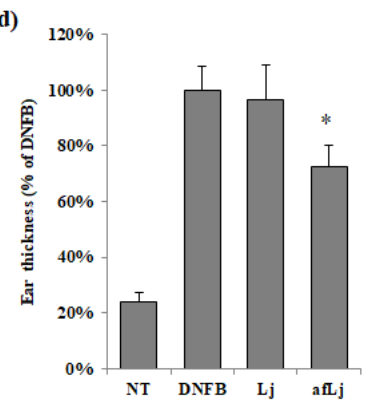

(e)

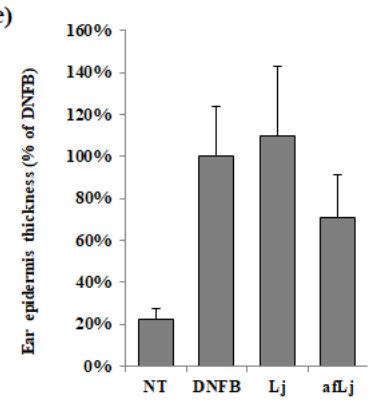

(f)

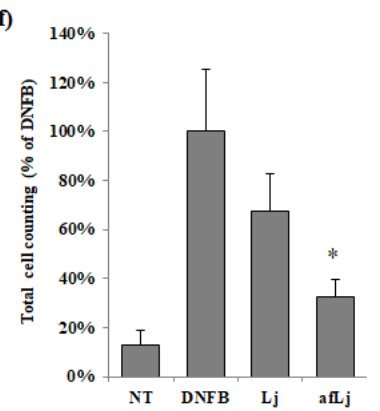

(g)

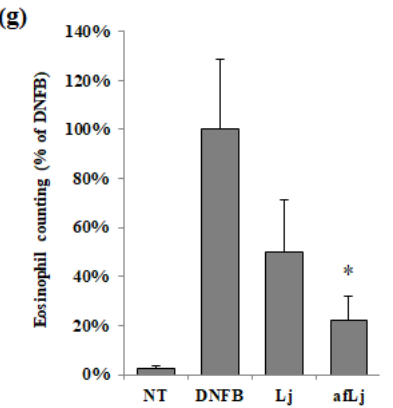

Fig. 2. Anti-atopic effects of Lonicera japonica stem by solid fermentation with Phellinus baumii in a DNFB-induced atopic model.

Without NT, all of sample group were treated to $0.2 \%$ of DNFB. NT: no treatment group, DNFB: 1-Fluoro-2,4-dinitrobenzene, Lj: Lonicera japonica, afLj: aqueous fraction produced by solid fermentation of Phellinus baumii on Lonicera japonica stem. Topical application was carried out by 6 times $(20 \mu \mathrm{L}$ of $100 \mu \mathrm{g} / \mathrm{mL}$ afLj). (a) A classical image of ears. Five mice was used for each group. (b,c) Histochemical analysis by HE staining. (b) 40x, (c) $100 \times$ magnifications. (d-g) The one-way analysis of variance was used with Tukey post-hoc test. ${ }^{\star} \mathrm{p}<0.05$. 


\section{$\beta-$ Hexosaminidase assay에 의한 활성 변화}

체내에 천식이나 비염과 같은 알레르기 반응이 일어날 경우, 비만세포에 히스타민이 분비된다. 히스타민은 비만 세포 내 과립에 존재하는데, $\beta$-hexosaminidase 또한 저장된 과립 내부에 존재하므로, 세포 밖으로 분비되는 현상 즉 탈과립(degranulation)의 지표로 이용되고 있다. 세포 밖으 로 분비된 이 효소 활성은, 알레르기 억제물질의 생리활성 측정에 유용하게 사용되고 있다(13).

먼저, 비만세포인 RBL-2H3 세포에서의 독성을 측정하 기 위해 MTT assay를 실시한 결과, $\mathrm{Ljd}$ 와 $\mathrm{afLj}$ 의 $3,10,30$ $\mu \mathrm{g} / \mathrm{mL}$ 농도에서 인동 및 인동 발효 추출물에서는 세포 독성 이 없는 것으로 판단되었다(Fig. 3a). 이 결과를 토대로, $\beta$ -hexosaminidase의 활성을 측정한 결과, $10 \mu \mathrm{g} / \mathrm{mL}$ 농도에서 는 대조군(control)에 대비하여 $\mathrm{Lj}$ 와 $\mathrm{afLj}$ 에서 각각 70 ,
$67 \%$ 의 활성을, $30 \mu \mathrm{g} / \mathrm{mL}$ 농도에서는 각각 $37,25 \%$ 로서 $\mathrm{afLj}$ 에서 일부 미미하게 활성이 증가한 것을 확인하였다 (Fig. 3b). 따라서, 세포수준에서 알레르기 반응에 의한 히스 타민 분비를 억제하는 활성은 인동추출물과 이의 발효추출 물 모두에서 유사한 활성을 나타내며, 발효에 따른 차이는 크게 없음을 확인하였다.

\section{항산화 활성의 감소확인}

발효 유무에 따른 항산화 활성을 비교하기 위하여, 항산 화 실험에 관한 3가지 assay를 실시하였다. DPPH 라디칼 소거능 측정 결과, $100 \mu \mathrm{g} / \mathrm{mL}$ 농도 기준으로 $\mathrm{Lj}$ 와 afLj에서 각각 $64 \%, 3 \%$ 로 발효 후에 라디칼 소거능이 약 $61 \%$ 감소한 것을 확인하였다(Fig. $4 \mathrm{a})$ (a)

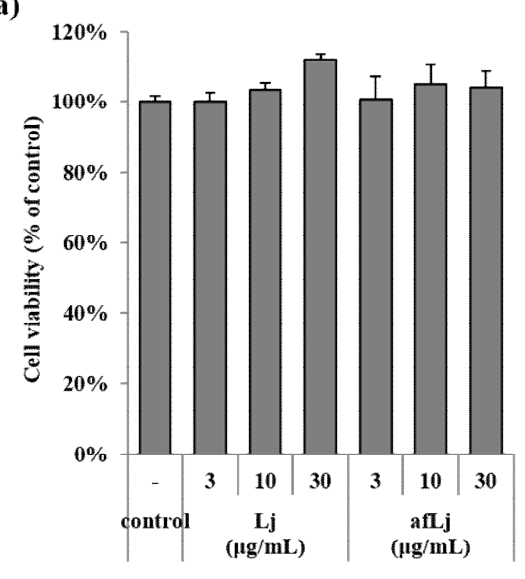

(b)

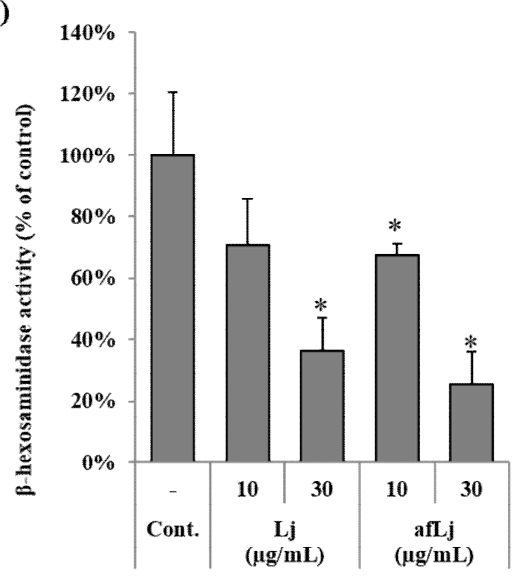

Fig. 3. Inhibitory effect of $\mathrm{Lj}$ on activity of $\beta$-hexosaminidase in RBL-2H3 cells stimulated with IgE - antigen.

(a) Cell viability by MTT assay was performed. (b) $\beta$-Hexosaminidase assay was performed using DNP-IgE. The values are means \pm SD with triplicate experiments. Lj: Lonicera japonica, afLj: aqueous fraction produced by solid fermentation of Phellinus baumii on Lonicera japonica stem. ${ }^{\star} \mathrm{p}<0.05$, compared to control group.

(a)

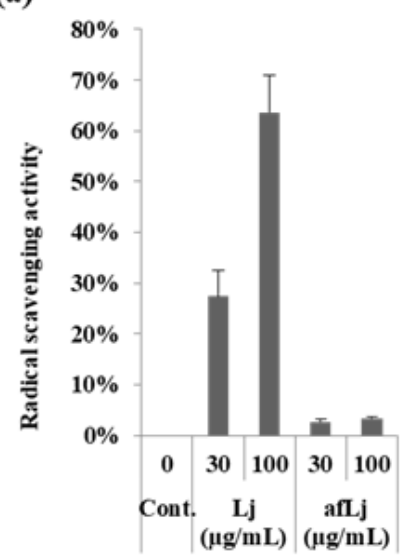

(b)

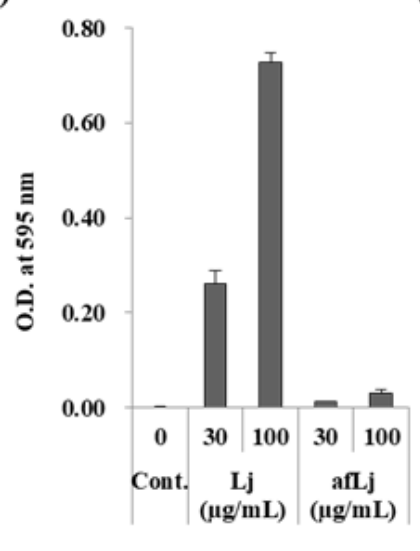

(c)

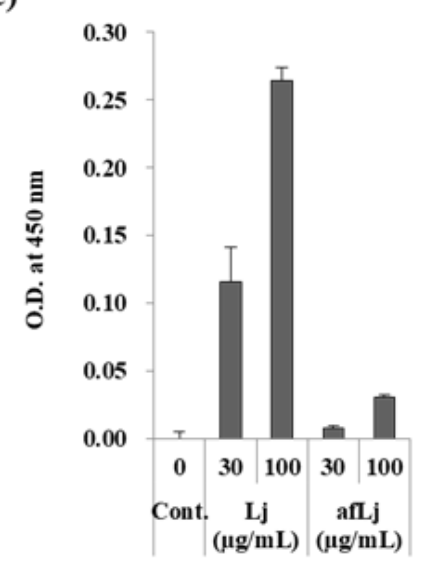

Fig. 4. Comparison of antioxidant activities of $\mathrm{Lj}$ and its solid fermented extract. $\mathrm{Lj}$ : Lonicera japonica, afLj: aqueous fraction produced by solid fermentation of Phellinus baumii on Lonicera japonica stem.

(a) DPPH assay, (b) FRAP assay, (c) CUPRAC assay. Statistical significance was performed by unpaired two-tailed students t-test. *p<0.05 compared with control. 
FRAP assay 결과에서도, $100 \mu \mathrm{g} / \mathrm{mL}$ 농도에서 $595 \mathrm{~nm}$ 의 O.D. 값은 $\mathrm{Lj}$ 와 afLj에서 각각 $0.727,0.030$ 으로서, 인동 자체 의 항산화 활성은 측정되나, 발효 후의 항산화능은 거의 없는 것으로 확인되었다(Fig. $4 \mathrm{~b})$. CUPRAC assay에서도, $100 \mathrm{\mu g} / \mathrm{mL}$ 농도에서 $\mathrm{Lj}$ 와 $\mathrm{afLj}$ 에서 각각 $0.265,0.031$ 의 흡광 도를 나타내었으며(Fig. 4c). 결과적으로, 항산화 3종의 실 험 모두에서 동일한 양상으로, 인동 추출물이 발효 후에는 항산화 활성이 급속히 감소한 것을 확인할 수 있었다.

\section{고 찰}

인동은 한의학적으로 유용한 약재로서 특히, 이를 건조 하여 만든 인동차는 부종이나 이뇨작용이 우수하여 건강차 로서 자리매김하였다. 이 인동은 현재까지 알려진 바로는 폴리페놀화합물이 다양하게 함유되어 있는데, tannin류, iridoide류, flavonoid류, triterpene류, saponin류 등이 대표적 인 기능성 물질이다. 이미 전보에서 Shin 등(14)은, 계피를 상황버섯 균사체로 고체발효시킨 추출물에서 $\mathrm{DNFB}$ 에 의 한 항아토피 활성을 연구하였다. 그 결과, 원재료 계피에 비해 발효시킨 추출물은 MMP-2, MMP-9, MMP-10의 억제 활성과 아토피 개선활성이 증가되는 것을 확인하였다. 본 연구에서는 이 소재이외에 상황버섯 균사체를 이용한 고체 발효가 항아토피 활성에 증진시키는 연구를 지속하던 중, 인동이 매우 우수한 활성을 보유함을 발견하게 되었다.

$\mathrm{DNFB}$ 를 이용한 아토피 유도의 모델에 비교하여, 집먼지 진드기가 실제 인체에 아토피를 유발하는 것이 더 유사한 모델(15)이므로, 이 방법으로 유도된 아토피 모델에서 인동 의 상황버섯 고체발효 추출물의 항아토피 활성을 검증해 볼 필요성이 있다고 사료된다. 특히, 아토피 증상에 따라 T-helper cell의 unbalance에 따라 증가하는 사이토카인 (IL-4, IL-13, IL-17E(IL-25), IL-31, IL-33)등의 조절 여부를 추가적으로 확인할 필요가 있다고 판단된다. 한편, 아토피 피부염에 사용되고 있는 덱사메타손(dexamethasone)과 같 은 스테로이드계 약물의 부작용과 유산균 생균의 부착률에 따른 아토피 피부염의 한계점을 극복하여 더욱 근본적인 아토피 피부염의 치료에 효과적인 유산균 제재 개발이 요구 되고 있다(15). 아토피 피부염을 치료하는 데 있어서 기존의 스테로이드계 약물의 약제내성 등의 부작용을 개선하기 위해 프로바이오틱스 연구가 대안으로 제시되었다. 이는 파라프로바이오틱스 제제로 실험적 입증단계로 집먼지 진 드기 항원으로 유발시킨 만성 아토피 피부염 동물모델에 경구투여함으로써 치료효과를 여러 가지 면역관련 바이오 마커를 통해 입증하고, 이를 바탕으로 만성 아토피 피부염 치료기전을 밝힐 수 있었다. 그 결과, 아토피 피부염 치료의 평가항목 중 하나인 SCORAD수치가 10점 수준에서 최대 2.3점으로 $71.3 \%$ 의 만성, 중증도 아토피 피부염 치료효과
를 나타내었다(15). 본 연구에서도 한약재가 다수의 약재를 사용하는 복방의 경우에는 더욱 에스트로겐 유사물질이 과다하게 검출될 수 있으므로 이러한 단점을 보완하기 위하 여 진균류에 의한 고체발효를 통하여 한약 자체가 지닌 독성물질을 저감화시키기 위한 일환으로 고체발효기법을 적용하였다. 그 결과, MTT assay에서도 공시 농도에서는 독성을 나타내지 않으며 항산화 활성을 나타내는 다수의 유용성분이 진균류에 의하여 소실되었음에도 불구하고 항 아토피 활성이 우수하게 나타난 특이한 발견이었다. Lee (16)의 연구에서는 마 품종별 고체발효시 항산화 활성이 장마, 병마, 둥근마에서 각각 $51.8 \%, 66.4 \%, 42.2 \%$ 에서 $64.7 \%, 74.7 \%, 52.8 \%$ 로 증가한다고 보고하였다. 또한, Son 등(8)은 약쑥의 잎을 영지버섯으로 고체발효시키고 이의 추출물을 조제하여 $\mathrm{DNFB}$ 에 유발된 아토피 유도 마우스에 도포하여 피부에 염증효과가 억제되는지의 여부를 확인한 결과, 귀 조직과 표피의 두께 및 피부 조직에서의 호산구 침윤은 고체 발효 과정을 거친 약쑥의 물 추출물에서 항아 토피 효과가 현저히 증가함을 발견하였는데, 아토피 증상 의 바이오마커인 산화 질소 (NO) 합성 효소 (NOSs), matrix metalloproteinase(MMP)-2, -7, -9, -12, -14 및 -19의 mRNA 발현이 강력하게 저해됨을 발견하였다. 이와 같은 결과는 약쑥의 물 추출물이 고체발효의 과정을 거치는 동안 유용한 화합물을 분비함으로서 항아토피 활성이 증가하였음을 입 증해 주는 결과로 추정되었다. 이와는 대조적으로 본 연구 결과에서는 항산화 활성이 급격히 감소(Fig. $4 \mathrm{a}-\mathrm{c}$ )하는데도 불구하고, 항아토피 활성이 증가(Fig. $2 \mathrm{~g}$ )하는 것을 보면, 최적의 생물변환(biotransformation)의 조건 최적화는 식물 소재의 효용성 증진에 필수불가결한 과정이라 할 수 있다. 이는 앞서 확인한 항아토피 활성이 발효 후에 증가한 것이 항산화와 관련된 물질(예를 들면 폴리페놀계의 화합물)들 이 고체 발효에 의해 변환됐을 가능성을 배제할 수 없으며 B-hexosaminidase assay에 의하여 고체발효한 인동 추출물 에서는 발효하지 않은 추출물에 비교하여 큰 차이가 나지 않는 것을 감안한다면, 고체발효에 의하여 항산화 물질이 특정 아토피 활성 물질로 변환 되었을 가능성이 높다고 판단되어지나 추후 더 확인이 필요하다고 사료된다. 발효 에 의해 항아토피 활성이 증가된 3종류의 발효 물질(상황발 효+계피, 상황발효+마황, 상황발효+복령)에서 $\mathrm{DNFB}$ 에 의 한 염증 유도 반응을 현저히 감소시킨 선행결과를 이미 확보하고 있으므로 이들에 대한 상세한 기전연구는 추후에 추진해 볼 만하며, 이 같은 효과는 이너뷰티나, 향장소재 개발에도 응용이 가능하리라 기대된다.

\section{요 약}

강력한 항아토피성 활성을 나타내는 여러 가지 약초 추 
출물을 선별하는 과정에서, 먼저 Phellinus baumii의 고형 발효 과정에 의한 Lonicera japonica stem extract (afLj)의 물 분획의 항아토피 효과를 확인했다. 그 결과, 동물실험에 서, 항아토피 활성은 대조군에 비해 증가하는 반면, afLj의 항산화 활성은 감소한다는 것을 밝혔다. 염증 부위로의 면 역 세포침윤은 DNFB로 유도한 마우스(NT)에 비해 대조군 의 $32 \%$ 수준으로 급격히 감소했다. 흥미롭게도, $\mathrm{afLj}$ 에 의 한 호산구의 수는 $\mathrm{Lj}$ 에 비해 현저하게 감소했다. 항산화 활성의 감소와 $\beta$-hexosaminidase 활성의 유의한 차이는 LJ 자체가 보유한 활성이 고체발효 과정에서 생물 변환을 통해 항아토피 활성물질로 전환되었음을 의미한다.

전체적으로, 이러한 결과는 afLj가 항아토피 활성에 관련 된 새로운 기능성 소재, 기능성 식품성분 또는 이너뷰티소 재로 사용될 수 있음을 시사한다.

\section{감사의 글}

이 논문(저서)은 2017학년도 경북대학교 연구년 교수 연 구비에 의하여 연구되었습니다. 제 1 및 제 2 저자는 BK21플 러스사업의 지원을 받았습니다.

\section{References}

1. Heo JC, Lee KY, Lee BG, Choi SY, Lee SH, Lee SH (2010) Anti-allergic activities of ultra-fine powder from persimmon. Korean J Food Preserv, 17, 145-150

2. Gantner F, Tenor H, Gekeler V, Schudt C, Wendel A, Hatzelmann A (1997) Phosphodiesterase profiles of highly purified human peripheral blood leukocyte populations from normal and atopic individuals: a comparative study. J Allergy Clin Immunol, 100, 527-535

3. Choi HJ, Sim BY, Miyamoto T (2015) Effects of Lobophytum crassum extract (MC-1) on various immunological factors related to pathogenesis of atopic dermatitis in Dermatophagoides pteronyssinus treated NC/Nga mice. Kor J Herbology, 30, 95-101

4. Son IP, Lim YY, Kim HM, Kim MY, Suk JM, Kim YH, Kim KH, Kim BJ, Kim MN (2012) The Effect of the mixed herbal extract lotion for Korean patient with atopic dermatitis: A pilot study. Korean J Asthma Allergy Clin Immunol, 2012, 32, 26-33

5. Pyo SS (2009) Development and validation of HPLC method for sweroside determination in honeysuckle (Lonicera japonica Thunb.) extract. Chungbuk National University, Korea, p 1-41
6. Shin JH, Yoo SK (2012) Antioxidant properties in microbial fermentation products of Lonicera japonica Thunb. extract. J East Asian Soc Dietary Life, 22, 95-102

7. Kim MA, Son HU, Nam DY, Cha YS, Shin YK, Choi YH, Lee SH (2012) Inhibitory effect of Angelica keiskei extract in an atopic dermatitis animal model. Korean $\mathbf{J}$ Food Preserv, 19, 792-798

8. Son HU, Lee S, Heo JC, Lee SH (2017) The solid-state fermentation of Artemisia capillaris leaves with Ganoderma lucidum enhances the anti-inflammatory effects in a model of atopic dermatitis. Int $\mathbf{J}$ Mol Med, 39, 1233-1241

9. Chung MJ, Ha TJ, Choi HN, Lee JS, Park YI (2011) Inhibitory effects of anthocyanins isolated from black soybean (Glycine max L.) seed coat on degranulation and cytokine generation in RBL-2H3 cells. J Korean Soc Food Sci Nutr, 40, 1662-1667

10. Kang SA, Han JA, Jang KH, Choue R (2004) DPPH radical scavenger activity and antioxidant effects of Cham-Dang-Gui (Angelica gigas). J Korean Soc Food Sci Nutr, 33, 1112-1118

11. Heo JC, Park JY, An SM, Lee JM, Yun CY, Shin HM, Kwon TK, Lee SH (2006) Anti-oxidant and anti-tumor activities of crude extracts by Gastrodia elata Blume. Korean J Food Preserv, 13, 83-87

12. Apak R, Guclu K, Ozyurek M, Karademir SE (2004) Novel total antioxidant capacity index for dietary polyphenols and vitamins $\mathrm{C}$ and $\mathrm{E}$, using their cupric ion reducing capability in the presence of neocuproine: CUPRAC method. J Agric Food Chem, 52, 7970-7981

13. Park SB, Kang KH, Yoon HJ, Ko WS (2011) Inhibitory effect of Ulmus davidiana on $\beta$-hexosaminidase release and cytokine production in RBL-2H3 cells. J Korean Med Ophthalmol Otolaryngol Dermatol, 24, 86-95

14. Shin YK, Heo JC, Lee JH, Lee SH (2010) Analysis of the anti-allergic activities of active components produced by solid fermentation of Phellinus baumii and Ephedra sinica. Korean J Food Preserv, 17, 297-300

15. Lee SH (2018) Therapeutic effects of tyndallized Lactobacillus rhamnosus IDCC 3201 on chronic atopic dermatitis induced by house dust mite. Konkuk University, Korea, p 1-118

16. Lee JG (2014) Antioxidant activities and Monacolin K production on solid-state fermentation of diverse Yam by Aspergillus species strain. Korean J Microbiol, 50, 53-59 